\title{
Benign Cervical Soft Tissue Neoplasm
}

National Cancer Institute

\section{Source}

National Cancer Institute. Benign Cervical Soft Tissue Neoplasm. NCI Thesaurus. Code C128053.

A rare benign mesenchymal neoplasm that arises from the cervix. 